\title{
ОТРУЄННЯ ФОСФОРОРГАНІЧНИМИ СПОЛУКАМИ: ВАРІАНТИ ПЕРЕБІГУ, ДІАГНОСТИЧНА ТА ЛІКУВАЛЬНА ТАКТИКА БРИГАДИ ЕКСТРЕНОЇ (ШВИДКОЇ) МЕДИЧНОЇ ДОПОМОГИ
}

Вступ. У даній статmі розглянуто різновиди фросфророрганічних сполук, шляхи їх надходження в організм, характерні клінічні прояви та сучасний алгоритм догоспітальної терапії в практиці бригади екстреної (швидкої) медичної допомоги (Е(Ш)МД). Актуальність даної проблеми полягає в тому, що левову частку всіх отруєнь становлять саме отруєння фросфророрганічними сполуками, оскільки їх досить широко застосовують у сільському господарстві, промисловості та медицині. Ці сполуки вирізняються широким діапазоном активності щодо шкідників сільськогосподарських культур.

Мета дослідження - підвищити якість діагностики та надання своєчасної кваліфрікованої догоспітальної медичної допомоги працівниками Е(Ш)МД постраждалим, отруєним фросфророрганічними сполуками.

Методи дослідження. Основним патогенетичним механізмом дії фосфоорорганічних сполукє пригнічення активності холінестерази - фрерменту, що гідролізує ацетилхолін і відіграє важливу роль у процесі синаптичної передачі нервового імпульсу в холінергічних синапсах. Гальмування активності холінестерази призводить до припинення або зменшення розщеплення ацетилхоліну, що зумовлює накопичення останнього і надмірне збудження ним холінореактивних систем. Отруєння фроссророрганічними сполуками викликає утворення фоссфоризованої холінестерази, яка втрачає здатність гідролізувати ацетилхолін і дуже повільно відновлює свою активність.

Результати й обговорення. Як свідчать результати проведених досліджень, клінічна картина впливу різних фроссророрганічних сполук на організм людини полягає в проявах з боку центральних або перифрерійних холінореактивних систем. Швидкість розвитку клінічних проявів залежить від механізмів надходження отрути в організм. Слід відзначити, що при інгаляційному впливі симптоми ураження з'являються дуже швидко. У разі проникнення крізь шкіру прихований період дії триває. При потраплянні отрути через дихальні шляхи на перший план виступають симптоми розладів дихання, при пероральному - системи травлення, крізь шкіру - м'язові фрібриляції. Далі, незалежно від механізмів проникнення фросфророрганічних сполук в організм, у клінічній картині гострого отруєння переважають симптоми загальнорезорбтивної дії сполук, яка проявляється симптомами ураження ЦНС (вегетативні центри, гіпоталамічні структури), органів зору (міоз, зниження гостроти зору, спазм акомодації), серцево-судинної системи (вегетосудинна дистонія, міокардіодистрофрія), травного каналу (гіперсалівація, коліки, дискінезії кишечника, жовчовивідних иляхів, токсичний гепатит), органів дихання (бронхоспазм, бронхорея), скелетних м'язів (судоми).

Висновки. Враховуючи поліморфрізм клінічних проявів отруєння фросфорорганічними сполуками та його ускладнень, надзвичайно важливо, щоб медики “швидкоі" освоїли, як розпізнавати дані патологічні стани і надавати кваліфріковану догоспітальну медичну допомогу. Через че комплексна догоспітальна екстрена медична допомога полягає в застосуванні амілнітриту, за наявності апное або при значному порушенні дихання - проведенні штучної вентиляції легень та інгаляції кисню. При послабленні серцевої діяльності слід використовувати розчин кордіаміну підшкірно, а при судинному колапсі рекомендують інгаляцію кисню та підшкірну ін'єкцію норадреналіну. Антидотна терапія полягає у введенні 20 мл хромосмону внутрішньовенно, в подальшому - 30 \% розчину натрію гіпосульфріту внутрішньовенно.

КЛЮчОВІ СЛОВА: фосфорорганічні сполуки; отруєння; екстрена (швидка) медична допомога; антидотна терапія; клінічні протоколи медицини невідкладних станів.

ВСТУП. Щоденна діяльність бригад екстреної (швидкої) медичної допомоги (Е(Ш)МД) пов'язана з різноманітними захворюваннями.

Фосоророрганічні пестициди розрізняють як препарати контактної (вбивають комах при контакті з їх тілом), кишкової (проникають в організм (с) Р. М. Ляхович, М. Я. Джус, Я. М. Кіцак, О. Г. Нецюк, 2017. через органи травлення) і фрумігантної (через дихальні шляхи) дії.

У промисловості фоосфорорганічні сполуки використовують як активні багатофрункціональні присадки до мастил, при фрлотації руд, у виробництві розчинників, пластифрікаторів, негорючих пластмас. Вони поєднують у собі властивості 
мийних, протикорозійних і протизносних присадок та є антиокиснювачами і депресорами $[1,2]$.

Як лікарські засоби застосовують для лікування глаукоми, міастенії, атонії кишок, хіміотерапії туберкульозу і раку. Вирізняються високою біологічною активністю, а багато з них $€$ найсильнішими серед відомих отрут. За хімічною структурою це складні ефріри та аміди фросфорних і фроссронових кислот.

Серед ороссророрганічних сполук є речовини з різною токсичністю для людини - від мало- до високотоксичних сполук. Окремі високотоксичні сполуки є бойовими отруйними речовинами нервово-паралітичної дії. Гранично допустима концентрація для різних фросфорорганічних сполук варіює від 0,02 до 0,5 мг/м³.

Серед високотоксичних та середньої токсичності пестицидів в Україні широко застосовують метилмеркаптофос, дихлофрос, бензофоссрат, хлорофос, метилнітрофрос, карбофрос.

Більшість фросфророрганічних сполук має різкий неприємний запах. Вони не стійкі у зовнішньому середовищі, розпадаються протягом 1-2 міс. У невеликій кількості відкладаються в продуктах харчування. Акумульовані в них, такі сполуки легко руйнуються під час термічної обробки. Практично всі погано розчиняються у воді й добре - в органічних розчинниках. Мають низьку і середню леткість.

Фосоророрганічні сполуки дуже стійкі, легко проникають в організм людини через легені, травний канал, слизові оболонки та шкірні покриви. У дуже малій кількості здатні порушити фрункції життєво важливих органів та систем і спричинити смертельні ураження. Отруєння розвивається в разі потрапляння у шлунок, через дихальні шляхи [3].

Проникнення таких сполук крізь шкіру зумовлене тим, що вони добре розчиняються в жирах і ліпідах. Потрапляння більшості представників цієї групи токсичних речовин на шкіру не спричинює подразнення, тому проникнення їх в організм через шкіру не залишає слідів. Має місце ефрект фрункціональної кумуляції при хронічному впливі на організм $[5,6]$.

Інактивація більшості фосфророрганічних сполук в організмі проходить шляхом гідролізу або хімічної взаємодії з білками протягом доби. У результаті окиснення утворюються більш активні метаболіти (сульфонові сполуки) порівняно $з$ тими, що потрапляють в організм. Це сприяє посиленню їх токсичного ефекту, але згодом фросоророрганічні сполуки гідролізуються і знешкоджуються. Виділяються із сечею у вигляді продуктів розпаду (паранітрофренолу) [4, 7, 13].

Саме ретельно зібраний анамнез, якісне первинне та вторинне обстеження дадуть змогу бригаді Е(Ш)МД провести правильну діагностику, а відтак розпочати надання своєчасної адекватної медичної допомоги. На сьогодні це залишається надзвичайно актуальною проблемою, оскільки досвід засвідчує, що, на жаль, нерідко слабкою ланкою в роботі бригад швидкої допомоги є саме недооцінка тяжкості стану постраждалого на місці події і пов'язаний із цим неадекватний обсяг медичної допомоги, що може призвести до серйозних ускладнень, а в окремих випадках - і до смерті постраждалого. Стає зрозумілим, що в даній ситуації роль надання невідкладної медичної допомоги на догоспітальному етапі $€$ вирішальною.

Мета дослідження - підвищити якість діагностики та надання своєчасної кваліфрікованої догоспітальної медичної допомоги працівниками Е(Ш)МД постраждалим, отруєним фроссророрганічними сполуками.

МЕТОДИ ДОСЛІДЖЕННЯ. Основний патогенетичний механізм дії фросфорорганічних сполук ґрунтується на пригніченні активності холінестерази - фрерменту, що гідролізує ацетилхолін і відіграє важливу роль у процесі синаптичної передачі нервового імпульсу в холінергічних синапсах. Ацетилхолін - медіатор парасимпатичного відділу вегетативної нервової системи, який бере участь у передачі збудження в центральній нервовій системі, всіх вегетативних гангліях, а також із рухових нервів до скелетних м'язів. У нормі ацетилхолін швидко утворює лабільний зворотний зв'язок із холінорецептором, що зумовлює зміни фрункціонального стану відповідних органів і тканин. Після відщеплення ацетилхоліну структура і властивості рецептора повертаються у вихідний стан. При цьому ацетилхолін відразу гідролізується холінестеразою. Холінестераза має два активних центри - аніонний та естеразний. За нормальних фрізіологічних умов аніонний центр притягує до себе катіонну частину ацетилхоліну, естеразний - ацетилюється залишком оцтової кислоти. Ацетилензим швидко гідролізується, і активні центри холінестерази знову вивільняються для нових реакцій 3 ацетилхоліном. Гальмування активності холінестерази призводить до припинення або зменшення розщеплення ацетилхоліну, що зумовлює накопичення останнього і надмірне збудження ним холінореактивних систем.

Отруєння фросфорорганічними сполуками викликає утворення фосфоризованої холінестерази (холінестераза + залишок фросоророрганічних сполук, що містить фросфор у вигляді залишку фросфрорної кислоти), яка втрачає здатність гідролізувати ацетилхолін і дуже повільно відновлює свою активність. 
Вважають, що не всі ефректи фросфорорганічних сполук можна пояснити антихолінестеразною дією. Можливо, в організмі людини є певні біохімічні системи, порушення діяльності яких призводить до виникнення симптомів інтоксикації, що лежать поза межами антиацетилхолінестеразної теорії. Встановлено, що, крім гальмування активності естераз, фоссророрганічні сполуки здатні також пригнічувати активність деяких протеаз (трипсину, хімотрипсину). Враховуючи основний механізм дії, з фрармакологічної точки зору, всі симптоми отруєння такими сполуками, які можна розглядати як ефекти, спричинені ацетилхоліном, поділяють на три групи: мускариноподібні, нікотиноподібні, центральні. Як правило, при отруєнні спочатку з'являються мускариноподібні симптоми, за ними нікотиноподібні, потім - центральні.

РЕЗУЛЬТАТИ Й ОБГОВОРЕННЯ. ЯК СВіДчать результати проведених досліджень, клінічна картина впливу різних фросфророрганічних сполук на організм людини в цілому подібна. Відмінності полягають лише в ступені проявів з боку центральних або периферійних холінореактивних систем, переважанні мускарино- чи нікотиноподібних ефректів, швидкості розвитку токсичного процесу. Розрізняють гостре і хронічне отруєння фоссророрганічними сполуками. Найбільш тяжка клінічна картина розвивається при гострих отруєннях, за яких необхідно проводити комплекс невідкладних заходів. Симптоми гострого отруєння з'являються раптово, його перебіг може бути легким, середньої тяжкості й тяжким. Швидкість розвитку клінічної картини залежить від механізмів надходження отрути в організм. При інгаляційному впливі симптоми ураження з'являються дуже швидко. У разі проникнення крізь шкіру прихований період дії триває [8-10].

Клінічна картина на початкових етапах розвитку інтоксикації зумовлена механізмом надходження фросфорорганічних сполук в організм. При потраплянні отрути через дихальні шляхи на перший план виступають симптоми розладів дихання, при пероральному - системи травлення, крізь шкіру - м'язові фрібриляції. Далі, незалежно від механізмів проникнення фросфорорганічних сполук в організм, у клінічній картині гострого отруєння переважають симптоми загальнорезорбтивної дії сполук, яка проявляється симптомами ураження ЦНС (вегетативні центри, гіпоталамічні структури), органів зору (міоз, зниження гостроти зору, спазм акомодації), серцево-судинної системи (вегетосудинна дистонія, міокардіодистрофія), травного каналу (гіперсалівація, коліки, дискінезії кишечника, жовчови- відних шляхів, токсичний гепатит), органів дихання (бронхоспазм, бронхорея), скелетних м'язів (судоми).

При легкому ступені ураження фоссророрганічними сполуками (міотична форма) розвиваються міоз і спазм акомодації. Виникають скарги на погіршення зору при слабкому освітленні, сльозотечу, біль у ділянках чола, очей, нежить, відчуття стиснення в грудях, слинотечу, нудоту, інколи - запаморочення, відчуття страху.

При середньому ступені ураження (бронхоспастична фрорма) виникають бронхоспазм, бронхорея, салівація. Ці явища характерні для інгаляційного шляху отруєння. При потраплянні на шкіру спостерігають інтенсивну пітливість і фрібриляцію м'язів на ураженій ділянці, а також слабкість м'язів, їх вираження, характер ускладнень та наслідки отруєння в більшості випадків залежать від тривалості гіпоксичного стану. Особливо часто відзначають порушення фрункції нервової системи, психіки.

Після перенесення гострого отруєння протягом декількох тижнів можуть бути головний біль, запаморочення, підвищена втомлюваність, порушення координації рухів, утруднена мова. Іноді розвиваються парез та параліч окремих груп м'язів. Спостерігають стійкі ознаки ішемії міокарда, фрункціональну лабільність дихального центру та швидке його виснаження при підвищених навантаженнях [11].

При небезпеці потрапляння синильної кислоти через органи дихання, для захисту органів дихання, очей та шкіри обличчя людини від впливу сильнодійних отруйних речовин у вигляді пари, туману, газу, диму, в краплинно-рідкому стані, які містяться в повітрі, використовують протигази. Дегазацію здійснюють шляхом провітрювання або розпилення формаліну в приміщеннях, де проводили роботи. Ефективність надання допомоги ураженим ціанідами залежить від швидкості застосування антидотів і засобів, що нормалізують фрункції життєво важливих органів та систем.

Антидотні властивості мають такі речовини:

- метгемоглобінутворювальні препарати (амілнітрит, пропілнітрит, фріцилін, натрію нітрат, метиленовий синій - частково чинить таку дію);

- акцептори водню (метиленовий синій, хроМОСМОH);

- речовини, які містять і виділяють сірку (30\% розчин натрію гіпосульсріту);

- альдегіди та кетони (вуглеводи - глюкоза);

- комплексоутворювальні препарати (комплексони - солі кобальту: гідроксикобаламін (вітамін $\mathrm{B}_{12}$, кобальтова сіль ЕДТА)).

Перша медична допомога. Одягнення або заміна несправного протигаза, розчавлення 
ампули з амілнітритом і закладання під маску протигаза. При рефрлекторній зупинці дихання виконання штучної вентиляції легень. Винесення постраждалого із зони ураження $[12,13]$.

Долікарська допомога. Повторне застосування амілнітриту, за наявності апное або при значному порушенні дихання - проведення штучної вентиляції легень та інгаляції кисню. При послабленні серцевої діяльності-використання розчину кордіаміну підшкірно, при судинному колапсі - інгаляція кисню, підшкірна ін'єкція норадреналіну.

Перша лікарська допомога. Антидотна терапія (спочатку введення 20 мл хромосмону внутрішньовенно, потім - 30 \% розчину натрію гіпосульфріту внутрішньовенно). Здійснення штучної вентиляції легень, інгаляції кисню, за показаннями - введення розчинів 1,5 \% етимізолу та кордіаміну по 2 мл внутрішньом'язово. При ураженні галоїдціанідами (ВгСК, ICN) та в разі виникнення токсичного набряку легень - введення аналептиків і серцевих засобів; проведення кровопускання 250-300 мл.

ВИСНОВКИ. Враховуючи поліморфрізм клінічних проявів отруєння фроссророрганічними сполуками та його ускладнень, надзвичайно важливо, щоб медики "швидкої" освоїли, як розпізнавати дані патологічні стани і надавати квалісріковану догоспітальну медичну допомогу. Через це комплексна догоспітальна екстрена медична допомога полягає в застосуванні амілнітриту, за наявності апное або при значному порушенні дихання - проведенні штучної вентиляції легень та інгаляції кисню. При послабленні серцевої діяльності слід використовувати розчин кордіаміну підшкірно, а при судинному колапсі рекомендують інгаляцію кисню та підшкірну ін'єкцію норадреналіну. Антидотна терапія полягає у введенні 20 мл хромосмону внутрішньовенно, в подальшому - 30 \% розчину натрію гіпосульфріту внутрішньовенно.

\section{Протокол кадання медично ̈̈ допомоги при отруєнні невідомою речовиною}

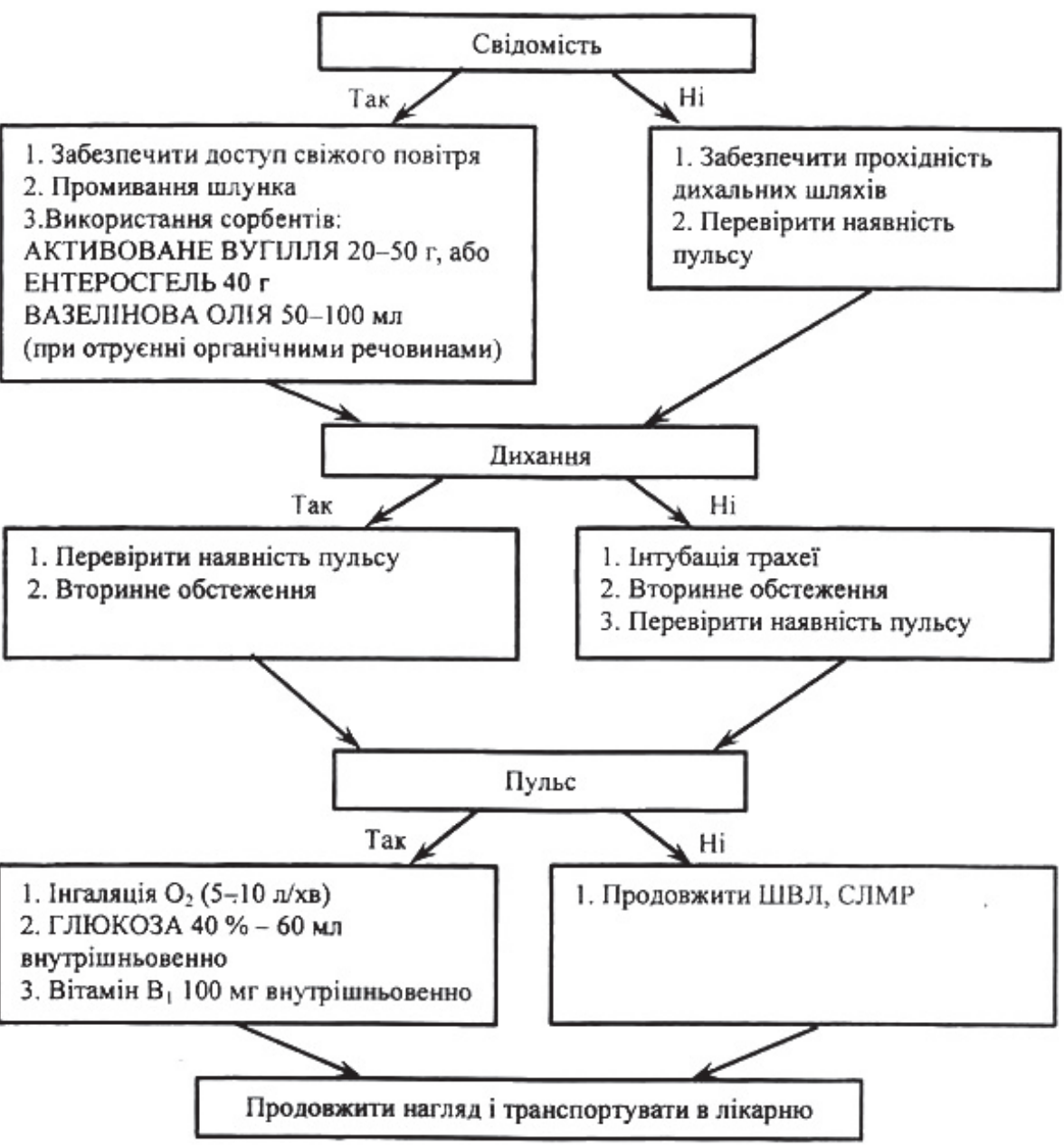

Примітка: 1. Взяти матеріал на хімічний аналіз

2. Визначити кількість та час приймання отрути 
Протокол наданкя медичної допомоги при отруєнні невідомим газом

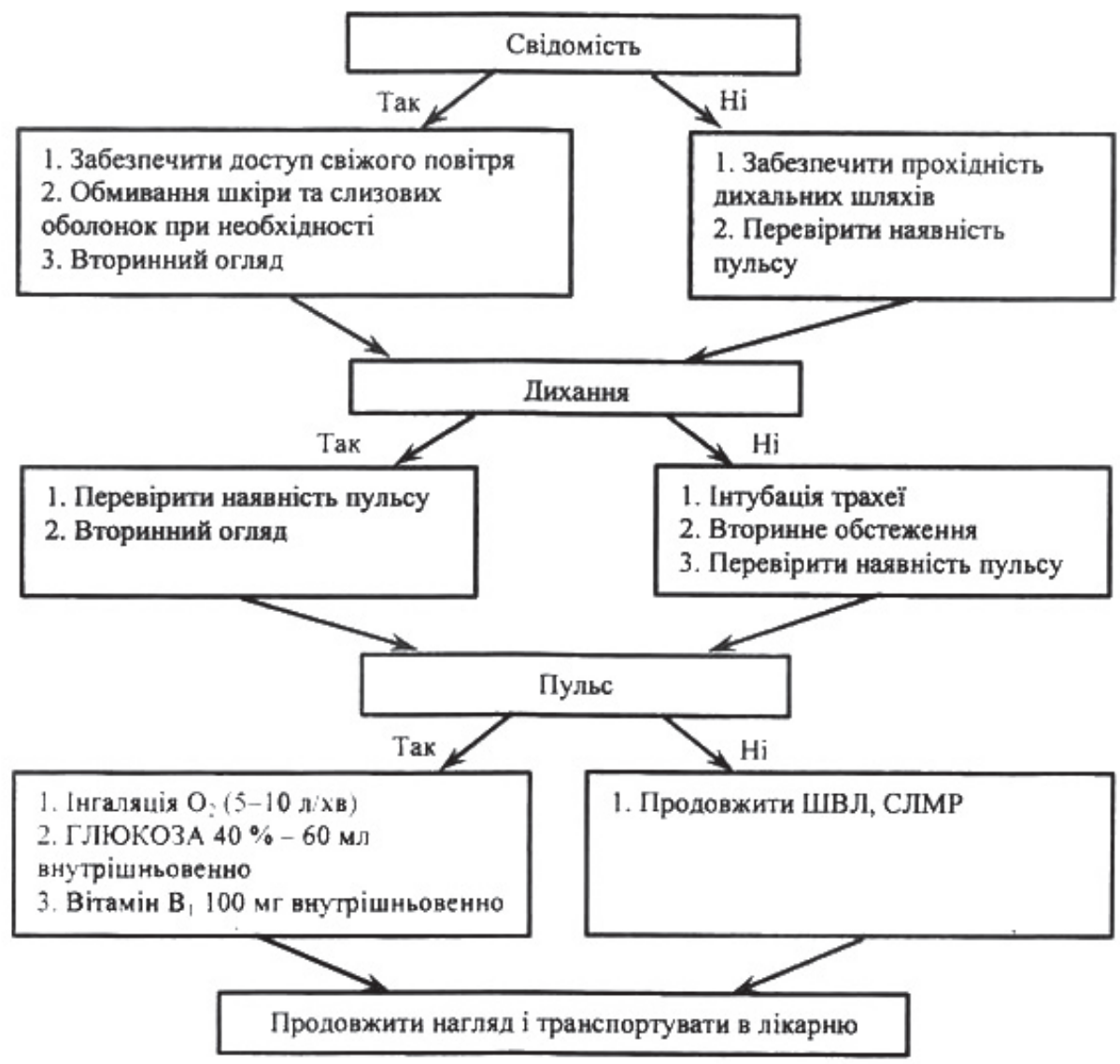

Примітка. При отруєнні відомим газом діяти згідно з цим протоколом із застосуванням специфічної (антидотної) тералії.

\section{СПИСОК ЛІТЕРАТУРИ}

1. Богомольний Б. Р. Медицина екстремальних ситуацій / Б. Р. Богомольний, В. В. Кононенко, П. М. Чув. - Одеса : Одес. держ. мед. ун-т, 2011. С. 67-81, 173-193.

2. Дубицький А. Ю. Медицина катастроф / А. Ю. Дубицький, І. О. Семенов, Л. П. Чепкий. - К. : КУРC, 2009. - C. 42-49.

3. Медицина катастроф / [В. І. Гридасов, В. М. Ковальов, М. В. Катрич та ін.]. - Харків : Вид-во НФаУ “Золоті сторінки", 2012. - С. 33-36.

4. Медицина катастрофр / [Г. О. Черняков, І. В. Кочін, П. І. Сидоренко та ін.]. - К. : Здоров'я, 2011. $352 \mathrm{c}$.

5. Військова токсикологія, радіологія та медичний захист : підручник / за ред. Ю. М. Скалецького, І. Р. Мисули. - Тернопіль : ТДМУ, 2013. - 362 с.

6. Медицина катастрофр (основы оказания медицинской помощи пострадавшим на догоспитальном этапе) / под ред. Х. А. Мусалатова. - М. : ГОУ ВУНМЦ МЗ РФ, 2002. - 448 c.
7. Сергеев В. С. Защита населения и территорий в чрезвычайных ситуациях / В. С. Сергеев. - М. : Академический проект, 2010. - 432 с.

8. Медицина неотложных состояний. Избранные клинические лекции / под ред. В. В. Никонова, А. Э. Феськова. - Донецк : Издатель Заславский А. Ю., 2008. - T. 1. - 503 c.

9. Невідкладні стани в медицині / за ред. В. П. Маленького. - Вінниця : Віноблдрукарня, 2000. - 350 с.

10. Середюк Н. М. Діагностика та лікування невідкладних станів і загострень терапевтичних захворювань / Н. М. Середюк ; за ред. Є. М. Нейка. Вінниця : Нова Книга, 2003. - 492 с.

11. Інтенсивна терапія невідкладних станів / за ред. І. І. Міщука. - Вінниця : Логос, 2006. - 277 с.

12. Неотложные состояния в клинике внутренней медицины / Н. И. Швец, А. В. Пидаев, Т. М. Бенца [и др.]. - К., 2006. - 752 с.

13. Медицина надзвичайних ситуацій. Організація надання першої медичної допомоги / за ред. В. С. Тарасюка. - К. : ВСВ “Медицина”, 2010. - 528 с. 
REFERENCES

1. Bohomolnyi, B.R., Kononenko, V.V., \& Chuv P.M. (2011). Medytsyna ekstremalnykh sytuatsii [Medicine of emergency situations]. Odesa: Odes. derzh. med. un-t [in Ukrainian].

2. Dubytskyi, A.Yu., Semenov, I.O., \& Chepkyi, L.P. (2009). Medytsyna katastrof [Medicine of catastrophes]. Kyiv: KURS [in Ukrainain].

3. Hrydasov, V.I., Kovalov, V.M. \& Katrych, M.V. (2012). Medytsyna katastrof [Medicine of catastrophes]. Kharkiv: Zoloti storinky [in Ukrainain].

4. Cherniakov, H.O., Kochin, I.V., \& Sydorenko, P.I. (2011). Medytsyna katastrof [Medicine of catastrophes]. Kyiv: Zdorovia [in Ukrainian].

5. Skaletskyi, Yu.M., \& Mysula, I.R. (Eds.). (2013). Viiskova toksykolohiia, radiolohiia ta medychnyi zakhyst: Pidruchnyk [Military toxicology, radiology and medical protection]. Ternopil: Ukrmedknyha [in Ukrainian].

6. Musalatov, Kh.A. (2002). Meditsina katastrof (osnovy okazaniya meditsinskoy pomoshchi postradavshim na dogospitalnom etape) [Medicine of catastrophes (bases of medical aid providing for injured at prehospital stage]. Moscow: GOU VUNMTs MZ RF [in Russian].

7. Sergeev, V.S. (2010). Zashchita naseleniya i territorii $v$ chrezvychainykh situatsiyakh [Protection of po- pulation and territory in emergency situations]. Moscow: Akademicheskiy proekt [in Russian].

8. Nikonova, V.V., \& Feskova, A.E. (Eds.). (2008). Meditsyna neotlozhnykh sostoyaniy. Izbrannye klinicheskie lektsii [Medicine of emergencies. Selected clinical lectures]. Donetsk: Zaslavskiy [in Russian].

9. Malenkyi, V.P. (Ed.). (2000). Nevidkladni stany v medytsyni [Emergency states in medicine]. Vinnytsia: Vinoldrukarnia [in Ukrainian].

10. Neiko, Ye.M. (2003). Diahnostyka ta likuvannia nevidkladnykh staniv i zahostren terapevtychnykh zakhvoriuvan [Diagnostics and treatment of emergency states and acute conditions of therapeutic diseases]. Vinnytsia: Nova Knyha [in Ukrainian].

11. Mishchuk, I.I. (Ed.). (2006). Intensyvna terapiia nevidkladnykh staniv [Intensive therapy of emergency states]. Vinnytsia: Lohos [in Ukrainian].

12. Shvets, N.I., Pidaev, A.V., Bents, T.M., Fedorov, O.A., \& Mironets, V.I. (Eds.). (2006). Neotlozhnye sostoianiya $v$ klinike vnutrenney meditsiny [Emergency states in the clinic of internal medicine]. Kyiv [in Russian].

13. Tarasiuk, V.S. (Ed.) (2010). Medytsyna nadzvychainykh sytuatsii. Orhanizatsiia nadannia pershoi medychnoi dopomohy [Medicine of emergency situations. Arrangement of first medical aid providing]. Kyiv: VSV Medytsyna [in Ukrainain].

Р. М. Ляхович, М. Я. Джус, Я. М. Кицак, А. Г. Нецюк ТЕРНОПОЛЬСКИЙ ГОСУДАРСТВЕННЫЙ МЕДИЦИНСКИЙ УНИВЕРСИТЕТ ИМЕНИ И. Я. ГОРБАЧЕВСКОГО

\section{ОТРАВЛЕНИЯ ФОСФОРОРГАНИЧЕСКИМИ СОЕДИНЕНИЯМИ: ВАРИАНТЫ ТЕЧЕНИЯ, ДИАГНОСТИЧЕСКАЯ И ЛЕЧЕБНАЯ ТАКТИКА БРИГАДЫ ЭКСТРЕННОЙ (СКОРОЙ) МЕДИЦИНСКОЙ ПОМОЩИ}

\section{Резюме}

Вступление. В данной статье рассмотрены разновидности фросфорорганических соединений, пути их поступления в организм, характерные клинические проявления и современный алгоритм догоспитальной терапии в практике бригады экстренной (скорой) медицинской помощи (Э(С)МП). Актуальность данной проблемы заключается в том, что львиную долю всех отравлений составляют именно отравления фросфророрганическими соединениями, поскольку их достаточно широко применяют в сельском хозяйстве, промышленности и медицине. Эти соединения отличаются широким диапазоном активности в отношении вредителей сельскохозяйственных культур.

Цель исследования - повысить качество диагностики и оказания своевременной квалифрицированной догоспитальной медицинской помощи работниками Э(С)МП пострадавшим, отравленным фросфророрганическими соединениями.

Методы исследования. Основным патогенетическим механизмом действия фросфорорганических соединений является угнетение активности холинэстеразы - фрермента, который гидролизирует ацетилхолин и играет важную роль в прочессе синаптической передачи нервного импульса в холинэргических синапсах. Торможение активности холинэстеразы приводит к прекращению или уменьщению расщепления ацетилхолина, что обусловливает накопление последнего и чрезмерное возбуждение им холинореактивных систем. Отравление фросфророрганическими соединениями вызывает образование фросфроризированной холинэстеразы, которая теряет способность гидролизировать ацетилхолин и очень медленно восстанавливает свою активность. 
Результаты и обсуждение. Как свидетельствуют результаты проведенных исследований, клиническая картина влияния различных фросфорорганических соединений на организм человека заключается в проявлениях со стороны центральных или периферических холинреактивных систем. Скорость развития клинических проявлений зависит от механизмов поступления яда в организм. Следует отметить, что при ингаляционном влиянии симптомы поражения появляются очень быстро. В случае проникновения через кожу скрытый период действия продолжается. При попадании яда через дыхательные пути на первый план выступают симптомы расстройств дыхания, при пероральном - системы пищеварения, через кожу - мышечные фрибрилляции. Далее, независимо от механизмов проникновения фросфророрганических соединений в организм, в клинической картине острого отравления преобладают симптомы общерезорбтивного действия соединений, которое проявляется симптомами поражения ЦНС (вегетативные центры, гипоталамические структуры), органов зрения (миоз, снижение остроты зрения, спазм аккомодации), сердечно-сосудистой системы (вегетососудистая дистония, миокардиодистрофия), пищеварительного тракта (гиперсаливация, колики, дискинезии кишечника, желчевыводящих путей, токсический гепатит), органов дыхания (бронхоспазм, бронхорея), скелетных мышц (судороги).

Выводы. Учитывая полиморфизм клинических проявлений отравления фросфророрганическими соединениями и его осложнений, чрезвычайно важно, чтобы медики “скорой” освоили, как распознавать данные патологические состояния и оказывать квалифицированную догоспитальную медицинскую помощь. Поэтому комплексная догоспитальная экстренная медицинская помощь заключается в применении амилнитрита, при наличии апноэ или в случае значительного нарушения дыхания - проведении искусственной вентиляции легких и ингаляции кислорода. При ослаблении сердечной деятельности следует использовать раствор кордиамина подкожно, а при сосудистом коллапсе рекомендуют ингаляцию кислорода и подкожную инъекцию норадреналина. Антидотная терапия заключается в введении 20 мл хромосмона внутривенно, в дальнейшем - 30 \% раствора натрия гипосульфита внутривенно.

КЛЮЧЕВЫЕ СЛОВА: фросфорорганические соединения; отравления; экстренная (скорая) медицинская помощь; антидотная терапия; клинические протоколы медицины неотложных состояний.

R. M. Liakhovych, M. Ya. Dzus, Ya. M. Kitsak, O. H. Necyuk I. HORBACHEVSKY TERNOPIL STATE MEDICAL UNIVERSITY

\section{POISONING WITH ORGANOPHOSPHORUS COMPOUNDS: VARIANTS OF THE COURSE, DIAGNOSTIC AND TREATMENT TACTICS OF THE EMERGENCY MEDICAL CARE BRIGADE}

\section{Summary}

Introduction. The article discusses the variety of organophosphorus compounds, ways of their intake, characteristic clinical manifestations and the modern algorithm of pre-hospital therapy in the practice of the emergency medical care brigade (EMC). The relevance of this problem lies in the fact that the total mass poisoning are poisoning with organophosphorus compounds (OPhC), because they are widely used in agriculture, industry and medicine. These compounds have a wide range of activity against pests of agricultural crops.

The aim of the study - to improve quality of diagnostics and administering of quality first medical aid by the EMC workers to the patients poisoned with phosphoorganic compounds.

Methods of the research. The main pathogenetic mechanism of action organophosphorus compounds is inhibition of cholinesterase activity - the enzyme which hydrolyzes acetylcholine and plays an important role in the process of synaptic transmission of the nerve impulse in cholinergic formations. Inhibition of cholinesterase activity leads to the cessation or reduce the breakdown of acetylcholine, which leads to the accumulation of the latter and excessive excitement they cholinergic system. Poisoning by organophosphorus compounds leads to the formation of cholinesterase, which loses the ability to hydrolyze acetylcholine, and very slowly recovers its activity.

Results and Discussion. Studies showed that the clinical picture of the effect of different organophosphorus compounds on the human body is the manifestation from the central or peripheral cholinergic systems. The rate of development of clinical manifestations depends on the mechanisms of admission of the poison into the body. If the poison gets through the respiratory tract, to the fore, appear symptoms of respiratory disorders, oral - digestive tract, 
through the skin - muscular fibrillation. Further, regardless of the mechanisms of penetration of organophosphorus compounds in the body, in the clinical picture of acute poisoning are manifested symptoms of affection of Central nervous system (the autonomic centers of the hypothalamic structures), eyes (miosis, decreased visual acuity, accommodation spasm), cardiovascular system (vegetative-vascular dystonia, myocardial), alimentary canal (hypersalivation, colic, dyskinesia of the intestine, biliary tract, toxic hepatitis), respiratory (bronchospasm, bronchure), skeletal muscles (convulsions).

Conclusions. Given the polymorphism of clinical manifestations of the poisoning and its complications is vital the familiarization of the brigade of emergency medical care these conditions and provide skilled pre-hospital medical care. Through this comprehensive pre-hospital emergency medical care is the use of amilnitrite, in the presence of apnea or with significant respiratory failure - artificial lung ventilation and inhalation of oxygen. With the weakening of cardiac activity should use the solution of cordiamin subcutaneously, but when the vascular collapse oxygen inhalation and subcutaneous injection of norepinephrine. Antidote therapy requires the introduction of $20 \mathrm{ml}$ of chromosone intravenous, further - 30 \% sodium hyposulfite intravenously.

KEY WORDS: organophosphorus compounds; poisoning; emergency medical care; antidote therapy; clinical protocols of emergency medical care.

Отримано 09.02.17

Адреса для листування: Я. М. Кіцак, Тернопільський державний медичний університет імені І. Я. Горбачевського, м. Волі, 1, Тернопіль, 46001, Україна, e-mail: kitsak@tdmu.edu.ua. 